\title{
Feasibility Analysis of Surface Rail in The Revitalization of The Railway Road
}

\author{
Wilton Wahab \\ Institut Teknologi Padang, Department of Civil Engineering, Padang, Indonesia
}

\begin{abstract}
The railway lines are an integral construction made of steel, concrete or other construction are located on the surface, below and above ground or dangling along with devices that direct the course of the train. Reflecting on the success of the revitalization of the railway line Padang-Pariaman, PT. Railway DIVRE II West Sumatra recently returned to the revitalization of the railway line Lubuk Alung-Kayu Tanam. In this final project feasibility analysis back to the road construction railroad Lubuk Alung-Kayu Tanam considering this path has not been used and an increase in the construction of the railroad on the route. The methodology used is the collection of data from related parties subsequently perform the calculation and analysis of railroad construction that has been revitalized. Data obtained from the calculation of the voltage rails on existing condition of $1380.34 \mathrm{~kg} / \mathrm{cm}^{2}$ and the voltage rails after revitalized by $840.601 \mathrm{~kg} / \mathrm{cm}^{2}$ while rail voltage maximum allowed is $1325 \mathrm{~kg} / \mathrm{cm}^{2}$, the rail existing deserves to be revitalized. Iron bearing on the condition of the existing able to withstand a load of $6761.69 \mathrm{~kg}$, while the load caused by railbus is $8568.986 \mathrm{~kg}$ so that the iron bearing existing not worth traversed railbus axle 18 ton and made improvement to the concrete pads. After upgrading, held their concrete pads capable of $23241.678 \mathrm{~kg}$ load and expenses incurred as a result of railbus axle 18 tons of concrete pads amounted to 6986.276. Concrete pads so deserve to be passed railbus axle 18 tons. The results of this thesis states that the construction of a rail road Lubuk Alung-Kayu Tanam deserves to be revitalized because of the condition of the existing construction rails and bearings are not able to withstand the stresses and loads that occur due railbus 18 tons passing through.
\end{abstract}

\section{Preliminary}

Transport has now grown into one of the most basic human needs. Starting from the smallest scope of human life, medium scope up to the widest scope. A country with different characteristics of its activities, its culture, and its physical, is definitely in contact with transportation. The effects of the need for movement/movement of people and goods will cause a demand for the provision of infrastructure and means of action to create a movement that goes with the condition of safe, convenient and smooth, and economical in terms of time and cost. In the end, the need for transportation is not only a natural need just, but it is necessary to have a good system so that the objectives of the above movements can be achieved [1]. The current evolving transportation system has embodied a form of ministry through various means of mechanistic movement that almost extends to all networks of territory on earth. Thus, today through modern transportation systems it is not difficult to reach the center of human activity from different angles of movement. The development of transportation technology in the future will be directed to the ability to overcome the demands of freight limitations, mileage, the speed of movement, comfort, safety, and cost reduction. In addition to the fulfillment of transportation limitations above, the dimension of transportation technology system will also be based on improving the quality of human life and the goals of fulfilling the needs of globalization. One example of the success of Indonesian transportation technology is the improvement of railway performance to reduce congestion due to the increase of private vehicles such as monorail and MRT (Mass Rapid Transit) in Jakarta [2].

West Sumatra as one of the developing provinces in Indonesia is also currently being incessant to develop railway transportation mode. As we know that the railway in West Sumatra had experienced suspended animation until in 2007 the Padang-Pariaman railway line was reactivated. The success of revitalization system and technology of transportation mode of railway transportation of Padang -Pariaman line need to be fully supported by good infrastructure. Not only the Padang - Pariaman railway course, beginning in November 2016 and DIVRE II WEST SUMATERA also reactivated the Lubuk Alung - Sicincin - Kayu Tanam railway line called the Pioneer Train. The difference is that if the Padang-Pariaman railway line is still crossed by BB locomotives, the Lubuk Alung-Kayu Tanam line is crossed by a railbus type train with an axle load of 18 tons, where the load is larger than the locomotive that usually crosses this line is 11 tons. In the revitalization of the railway that was once vacuumed

\footnotetext{
* Corresponding author: wahab.wilton@yahoo.com
} 
at the beginning of 2000, DIVRE II SUMATERA BARAT has been rebuilding or repairing infrastructure in the form of emplacement, road equipment, security and telecommunication, lighting, water supply and others that support the smooth revitalization of railway Lubuk Alung - Kayu Tanam [3-7].

\section{Study of Literature}

According to Ministerial Regulation No. 60 of 2012 on the technical requirements of the railway line, the speed is divided into speed of plan, maximum speed, operation speed and commercial speed.

Axle pressure is the load received by the rail of an axle. For all classes, the maximum axle load is 18 tones. To calculate the maximum axle pressure, it can use the formula.

$$
\overline{\mathrm{P}}=\frac{0,4}{1+\mathrm{C}} \times \frac{\mathrm{G}}{\mathrm{a}}
$$

To be able to determine the strength of a rail in holding the load through it can be confused using some of the following formulas:

a. Load Calculation on Boogie $(\mathrm{Pb})$

$$
\mathrm{Pb}=\frac{\mathrm{W} \text { locomotive }}{2} \text {... }
$$

b. Load Charge

$$
\operatorname{Pg}=\frac{\text { Heavy Style On Boogie }}{2}
$$

c. Static Load Calculation (Ps)

$$
\text { Ps }=\frac{\text { Style On Gandar }}{2}
$$

d. Dynamic Load Calculation $(\mathrm{Pd})$

$\operatorname{Pd}=\operatorname{Ps}\left(1+0,01\left(\frac{V_{\text {maks }}}{1,609}\right)-5\right) \ldots$

e. Calculation of Reduction Factor / Damping (damping Factor, $\lambda$ )

$$
\lambda=\sqrt[4]{\frac{\mathrm{K}}{4 \mathrm{EI}_{\mathrm{x}}}}
$$

Where:

$\mathrm{K}=$ Modulus of Elasticity of Rail Road

$\mathrm{E}=$ Modulus of Elasticity of Steel Constructor of Railway

$\mathrm{Ix}=$ Moment of Inertia Rail

f. Maximum Moment Calculation (Mm)

$$
M_{m}=\frac{\mathrm{Pd}}{4 \lambda}
$$

Where:

$$
\begin{aligned}
& \mathrm{Pd}=\text { Dynamic Load } \\
& \lambda=\text { Rail Reduction Factor }
\end{aligned}
$$

g. Voltage Calculation Happened $(\delta)$

$$
\sigma=\frac{M_{1} x Y}{I_{x}}
$$

Where:

M1 = The moment due to the superposition of some axles $(0.85 \times \mathrm{Mm})$
$\mathrm{Y}=$ Distance of bottom edge of rail to neutral line The value of the voltage that occurs on the rail shall not exceed the rail permit voltage according to JNR in Regulation No. 10, 1986 presented in the following table 1 :

Table 1. Regulation No. 10, 1986

\begin{tabular}{|c|c|c|c|}
\hline Class & Rail & $\begin{array}{c}\text { Voltage } \\
\text { (kg/cm2) }\end{array}$ & $\begin{array}{c}\text { Permit Voltage } \\
\text { (kg/cm2) } \\
\text { According to } \\
\text { JNR }\end{array}$ \\
\hline \multirow{2}{*}{ I } & R 60 & 1042 & 1325 \\
R 54 & 1195 & 1325 \\
\hline \multirow{2}{*}{ II } & R 54 & 1146 & \\
& R 50 & 1236 & 1663 \\
\hline \multirow{2}{*}{ III } & R 54 & 1097 & \\
& R 50 & 1183 & 1843 \\
\hline \multirow{2}{*}{ IV } & R 42 & 1474 & 1843 \\
& R 50 & 1130 & \\
\hline V & R 42 & 1409 & \\
\hline
\end{tabular}

Steps to calculate the imposition according to Regulation No. 10 of 1986 are as follows:

a. Calculation of Train Charge Distribution to Bearing (Q)

$$
Q=2 \times F \times S
$$

Where:

$$
\begin{aligned}
& Y_{\max }=0,393 \times \frac{P d}{K \cdot X_{1}} \\
& X_{1}=\frac{\pi}{4 \lambda}
\end{aligned}
$$

b. Calculation of Bearing Reduction Factor (Dumping Factor, $\lambda$ pads)

$$
\lambda=\sqrt[4]{\frac{\mathrm{K}}{4 \mathrm{EI}_{\mathrm{x}}}}
$$

c. Calculation of Moments at Points C and D (Right at the Bottom of the Rails)

$$
M_{c / d}=\frac{Q_{1}}{4 \lambda} \times \frac{1}{\sin \lambda L+\sinh \lambda L} \times\left[\begin{array}{c}
2 \cosh ^{2} \lambda a(\cos 2 \lambda c+\cosh \lambda L)- \\
2 \cos ^{2} \lambda a(\cosh 2 \lambda c+\cos \lambda L)- \\
\sinh 2 \lambda a(\sin 2 \lambda c+\sinh \lambda L)- \\
\sin 2 \lambda a(\sinh 2 \lambda c+\sin \lambda L)
\end{array}\right]
$$

d. Calculation of Moment in Middle Bearing

$$
M_{0}=-\frac{l_{1}}{2 \lambda} x \frac{1}{\sin \lambda L+\sinh \lambda L} \times\left[\begin{array}{c}
\{\sinh \lambda c(\sin \lambda c+\sin \lambda(L-c))\}+ \\
\{\sin \lambda c(\sinh \lambda c+\sinh \lambda(L-c)\}+ \\
\{\cosh \lambda c x \cos (L-c)\}- \\
\{\cos \lambda c x \cosh \lambda(L-c)\}
\end{array}\right] \ldots \ldots(14)
$$

e. Calculation of the moment that can hold the bearing Assumption $M_{S}=M_{\text {bearing }}$

$$
M_{\text {bearing }}=\left(\frac{5}{6} \tau_{1}\right) \times W \text {. }
$$


Where:

$\tau=$ Bearing permit voltage by type Bearing Load

Calculation (Q1)

$$
Q_{1}=\frac{M_{\text {Bearing }}}{M_{c / d}}
$$

f. Bearing Analysis

The bearing load analysis shall qualify that the load capacity of being retained by the binate shall be higher than the load incurred.

$$
\left(\mathrm{Q}_{1}>\mathrm{Q}\right)
$$

\section{Discussion}

The preparation stage is the stage of activity before beginning data collection and processing. To analyze the construction of the railway road Lubuk Alung - Wood Planting required data related to the objectives to draw the right conclusions, therefore conducted data inventory through agency surveys, interviews with related parties whose policies have influence and relationship to the perfection of construction. At this stage, the data processing for the calculation of the construction of railbus 18 tons and the maximum speed of $60 \mathrm{~km} /$ hour is calculated; (1). Existing rail construction analysis (R33), (2) Analysis of existing bearing construction, (3) Analysis of rail construction after revitalization (R54), (4) Analysis of bearing construction after revitalized (concrete). To facilitate the calculation of the calculation of the rails and pads can be seen in the following table 2 :

Table 2. Comparison of Voltage Occurring and Rail

\begin{tabular}{|c|c|c|c|}
\hline \multirow[b]{2}{*}{$\begin{array}{l}\text { Rail } \\
\text { Type }\end{array}$} & \multicolumn{2}{|c|}{$\begin{array}{l}\text { Occurred voltage }< \\
\text { Permit voltage }\end{array}$} & \multirow[b]{2}{*}{ Explanation } \\
\hline & $\begin{array}{c}\text { Occurred } \\
\text { voltage } \\
\left(\mathrm{Kg} / \mathrm{cm}^{2}\right)\end{array}$ & $\begin{array}{c}\text { Rail } \\
\text { Permit } \\
\text { Voltage } \\
\left(\mathrm{Kg} / \mathrm{cm}^{2}\right)\end{array}$ & \\
\hline R33 & 1380,34 & \multirow{2}{*}{1325} & Unsatisfactory \\
\hline R54 & 840,601 & & Satisfying \\
\hline
\end{tabular}
Permit Tension

Table 3. Comparison of expenses that can be bearing and the distribution load from rail to bearing

\begin{tabular}{|c|c|l|l|}
\hline \multirow{2}{*}{$\begin{array}{c}\text { Bearing } \\
\text { Type }\end{array}$} & $\begin{array}{l}|c| \\
\text { Resistibl } \\
\text { e loads } \\
\left(\mathrm{Q}_{1}\right)\end{array}$ & $\begin{array}{l}\text { Distribution } \\
\text { load from } \\
\text { rail to } \\
\text { bearing }(\mathrm{Q})\end{array}$ & Explanation \\
\hline Steel & $\begin{array}{c}6761,39 \\
\mathrm{Kg}\end{array}$ & $\begin{array}{l}\text { Unsatisfactor } \\
\mathrm{y}\end{array}$ & $\begin{array}{l}\text { Unsatisfactor } \\
\mathrm{y}\end{array}$ \\
\hline $\begin{array}{c}\text { Concret } \\
\mathrm{e}\end{array}$ & $\begin{array}{c}840,601 \\
\mathrm{Kg}\end{array}$ & Satisfying & Satisfying \\
\hline
\end{tabular}

From the table 3, we can see that on the existing condition of railway line Lubuk Alung - Kayu Tanam using rail type $\mathrm{R} 33$, the voltage that occurs on the rail if traversed by railbus with axle 18 tons is $1380.34 \mathrm{~kg} /$ $\mathrm{cm}^{2}$, this value is greater than the voltage permitted under Regulation No. 10 of 1986 is $1325 \mathrm{~kg} / \mathrm{cm} 2$, this means that the $\mathrm{R} 33$ rail is not feasible to be traversed by the railbus and must be replaced with larger rail dimensions.

The load distribution occurring on the pads due to a railbus axle pressure of 18 tones is $8568,898 \mathrm{~kg}$, and greater than the load capacity of being retained by iron bearings $6761,39 \mathrm{~kg}$, therefore the iron bearings are not feasible to pass by a railbus rail type 18 train ton. Increasing the dimension of rail type R33 to rail type R54 produce rail voltage of $840,601 \mathrm{~kg} / \mathrm{cm} 2$. The resulting voltage which is smaller than the maximum voltage permitted by JNR in Regulation No. 10 of 1986 amounted to $1325 \mathrm{~kg} / \mathrm{cm} 2$. Then the R54 type rail is safely traversed by a railbus railway type of 18 tons. Substitution of the type of iron-bearing into concrete pads produces a bearable load of bearings of 23,241,678 $\mathrm{kg}$, and this is greater than the distributed load that occurs on the bearing that is $6986,277 \mathrm{~kg}$. Thus the concrete bearing is able to withstand the burden of railbus with axle 18 tons.

Physically, the existing condition of Lubuk Alung Kayu Tanam railway line that was built during the Dutch colonial period was designed to be traversed by the locomotive of BB type with 11 tons. The existence of train development in the world is very influential on the development of railways in Indonesia. Due to the demands of technological development and transportation efficiency required Up-Grade and revitalization so that the long railway is not operated adjusted to a load of locomotives through it, especially the railway line Lubuk Alung - Kayu Tanam. Currently, the railway track class of Lubuk Alung - Kayu Tanam has been upgraded from class II level I to class I road.

Based on the Regulation of the Department (PD) No. 10 of 1986 that the first class rail tracks using rail type R54 and R60 (see table), so DIVRE II West Sumatra to increase dimensions of crossroads Lubuk Alung - Kayu Tanam from R33 to R54 by considering several factors other than the permit rail and bearing stress factors that have been analyzed beforehand although the volume of traffic on this line has not been as many as other class I lanes.

The first-class road in the revitalization of the Lubuk Alung-Kayu Tanam railway line is not the only reason for the writer to choose R54 instead of R33. Mediumterm and long-term development plans are also taken into account in the selection of rail dimensions, namely the Trans Sumatra railway which is planned to be operational for several years. If this revitalization activity starts from the increase of rails R33 to R42 which is the smallest dimension according to PD 10 the year 1986 with the rail age ranged between 35-40 years then in terms of economic aspects are less profitable and will happen waste. When the Trans Sumatra route has activated the rail and bearing construction must also be adjusted to traffic volume, type of locomotive, train type and axle load through it. That is the reason why R54 as one of the best dimensions at this time according to Regulation of Service (PD) 10 the year 1986 was chosen as replacement dimension of R33 in the revitalization of railway line of Lubuk Alung - Kayu Tanam

Although the railway class at the crossroad of Lubuk Alung - Kayu Tanam has increased to become the first 
class railway with a maximum speed of $120 \mathrm{~km} / \mathrm{h}$ (Regulation of Service (PD.10) 1986), but the relatively hilly West Sumatera geographical condition causes the limited geometric improvement of railroads such as arch and bend so that PT. Kereta Api Indonesia provides specific rules that the maximum speed for the railroad in West Sumatra is only $60 \mathrm{~km} / \mathrm{h}$, and it is not possible to meet the maximum speed required.

\section{Conclusion}

1. The voltage occurring at the rail in the existing condition is $1380.34 \mathrm{~kg} / \mathrm{cm} 2$ and greater than the permitted voltage acceptable by the rail $1325 \mathrm{~kg} /$ $\mathrm{cm} 2$, it is necessary to increase the rail dimensions.

2. The load distribution from a train to bearing in existing conditions is $8568,986 \mathrm{~kg}$, while the load capable of being retained by R33 iron bearing is only $6761,59 \mathrm{~kg}$, the value is not eligible so that the iron-bearing must be replaced.

3. After increasing the dimension of the railway line, Lubuk Alung-Kayu Tanam can be seen that the voltage that occurs on the rail is equal to 840,601 $\mathrm{kg} / \mathrm{cm} 2$, the voltage that occurs on the rail is smaller than the permitted voltage that can be held by rail of $1325 \mathrm{~kg} / \mathrm{cm} 2$.

4. The replacement of the iron-bearing to the concrete pads in the revitalization of the railway line of
Lubuk Alung-Kayu Tanam following the required standard of bearings capable of holding 23241,678 $\mathrm{kg}$ bearings greater than the load that occurs on the bearing $6986,276 \mathrm{~kg}$.

5. Overall, it can be concluded that the improvement of rail and bearing construction in the revitalization of the Lubuk Alung - Kayu Tanam railway line is feasible.

\section{Referensi}

1. Darmawan, Teknologi Jalan Rel, PT Kereta Api Indonesia: Bandung. (2001)

2. Surakim, H., Konstruksi Jalan Rel dan Keselamatan Perjalanan Kereta Api, Nuansa Cendikia: Bandung. (2014).

3. Sunggonokh, Teknik Sipil,: Bandung. (1995)

4. Perumka, Peraturan Dinas (PD) No 10, Tahun 1986 PT. Kereta Api Indonesia (Persero): Bandung, (1986)

5. Peraturan Menteri Perhubungan Republik Indonesia No.60 Tahun 2012 tentang Persyaratan Teknis Jalur Kereta Api, Jakarta.

6. Peraturan Pemerintah No.56 Tahun 2009 tentang Penyelenggaraan Perkeretaapian: Jakarta

7. Undang-Undang No.23 Tahun 2007 tentang Perkeretaapian: Jakarta 